\title{
The effect of number and position of braced frames on column behavior of the dual steel structural system (MRF and EBF) (With a view on amplified seismic load)
}

\author{
Sajjad Mohammadi ${ }^{1}$, Abd-ol-Reza Sarvghad Moghaddam ${ }^{2, *}$, Alireza Faroughi ${ }^{3}$ \\ ${ }^{1}$ Department of Civil Engineering, College of Civil Engineering, Semnan branch, Islamic Azad University, \\ Semnan, Iran. \\ ${ }^{2}$ Assosciate Professor in International Institute of Earthquake Engineering and Seismology, Tehran, Iran. \\ ${ }^{3}$ Faculty member of Civil Engineering Department, Islamic Azad University (East Tehran branch), Tehran, \\ Iran. \\ * Author: a.sarvghad.moghadam@gmail.com
}

\begin{abstract}
In seismic design of structures, determination of number and position of braced frames, considering the architectural scheme of projects, is usually confronted by obstacles. Due to this fact, in some cases, selecting the best location and number of braced bays has led to mistakes in determination of their adjacent members (columns) design loads. One of the seismic design requirements of lateral resisting system is to control the columns adjacent to braced bays for load combinations of amplified seismic load, which is a function of overstrength factor of the structure. This research aims to present and introduce the best structural model of number and position of braced frames in a structural system, such as steel moment resisting frame and eccentric braces dual system; because in 3rd revision of Iranian 2800 standard of seismic provision, there are statements and criteria provided only for capacity of moment frame, not for braces. Though the amplified seismic load function is controlled in models which columns are connected to braces in 2 directions, and seismic loads are applied in those 2 directions, number of damage hinges (Exceeding $C P$ ) is significantly increased in comparison to the models with straggly braces. As the increase in axial force of these columns leads to decrease in their moment capacity (despite controlling the amplified seismic load provision), columns in dual systems that resist flexure, would be damaged and exceed the collapse threshold much sooner than other columns. This important fact is not presented in Iranian or even American codes and provisions.
\end{abstract}

Keywords: Number and position of braced frames ${ }^{1}$, Over-strength factor ${ }^{2}$, Dual system of steel $^{3}$, 3rd revision of Iranian 2800 standard of seismic provision ${ }^{4}$, Amplified seismic load $^{5}$ 


\section{Introduction}

$\mathrm{M}$ oment resisting frame is a structural system which gravitational loads are carried by structural frames and lateral resistance is provided by moment frames. Structures totally consisting of moment frames, and structures with peripheral moment frames or structures with moment frames in some parts and simply supported frames in others, are moment resisting frames too. In this system, concrete or steel moment resisting frames can be used as ordinary, intermediate or special ductility frames. Most of the gravitational loads are carried by simply supported frames, and lateral loads are resisted by shear walls, braces or frames -with respect to lateral stiffness of each frame-. Shear resisting share of each group is determined in each story, considering their lateral stiffness and interaction $\left[3^{\text {rd }}\right.$ revision of Iranian 2800 standard of seismic revision - Code, 2005].

Eccentrically braced frames were introduced by Popov et al. in 1978 for the first time. This system was developed to resist the lateral loads and their effects on remarkable large deformations and relative displacements, especially in tall buildings. Eccentrically braced frames (EBF) were introduced as a modern seismic resisting system in codes and provisions as a result of this research. Based on the numerous researches conducted on this system, eccentrically braced frame systems can demonstrate high stiffness in inelastic region. The primary goal of developing eccentrically braced frames, was to induce yielding in a small part of beam, namely link beam [Merovich et al., 1982] [Roeder and Popov, 1978].

\section{Research Subject}

The aim of this research is to investigate the seismic capacity of dual systems of steel moment resisting frame and eccentric braces, to find the number and position of braced frames, related to this capacity, and to control the amplified seismic load. Also, the fact that columns in dual systems that resist flexure, would be damaged and exceed the collapse threshold much sooner than other columns is not presented in Iranian or even American codes and provisions; and in 3rd revision of Iranian 2800 standard of seismic provision, there are statements and criteria provided only for capacity of moment frame, not for braces and shear walls. These phenomenas are investigated of in this research

\section{Investigated Models}

FEMA p695-2009 is used for the investigation and acknowledgement of model selection requirements. By applying this provision, the following models were selected for the investigation.

\section{Design Considerations}

Using an experimental approach in design, the number of required braces were selected considering 10-30 percent of the structure perimeter. Number of structural models were limited to 28, due to their importance. The utilized sections in software models were all box sections with properties similar to common sections from size 8 to 40 (The following models, numbered from 1 to 28 from left to right respectively, were analyzed).

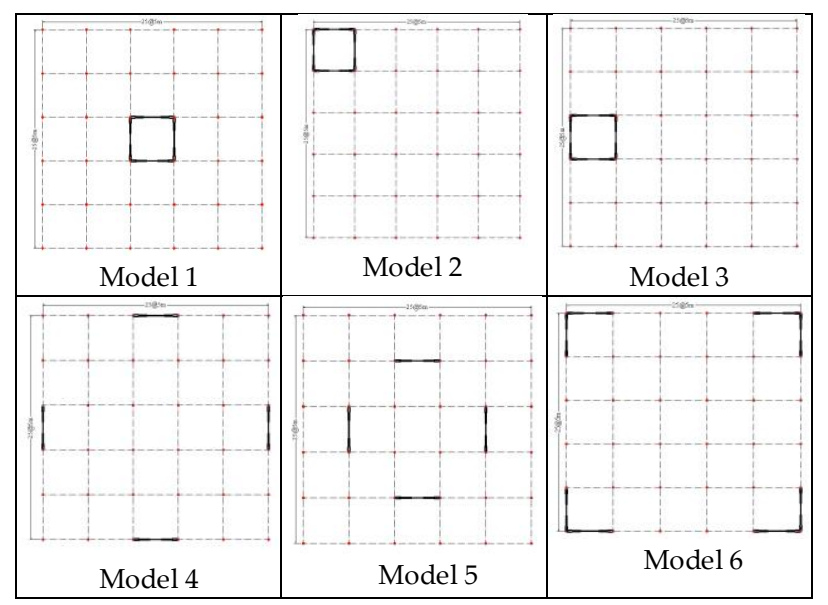




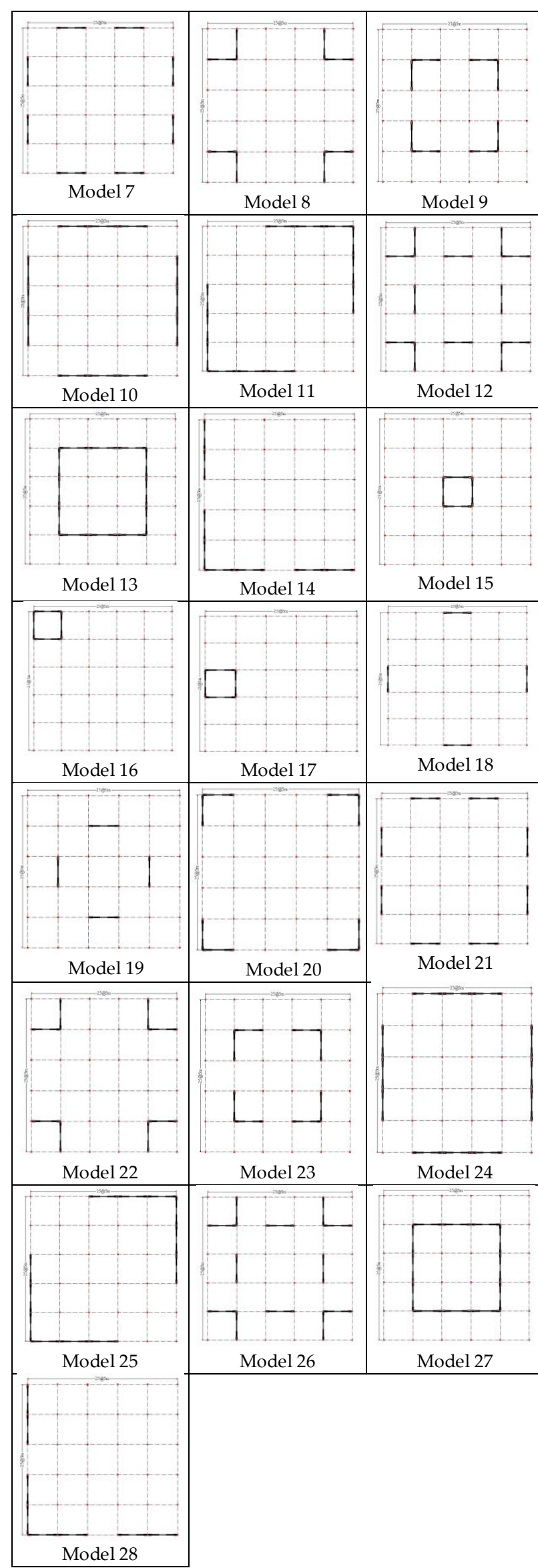

Figur. 1. Research models

\section{Design and Analysis methods}

Structural design was performed using Iranian design codes [Code 10,6 of Iranian national building] and 3rd revision of Iranian 2800 standard. To control and verify software calculations, some cases were calculated manually and compared with software results. The errors -if presented- were resolved and troubleshot.

\section{Moment resisting frames design provisions}

6.1 Provisions of 3rd revision of Iranian 2800 standard of seismic provision

6.1.1 Controlling moment frame under $25 \%$ of seismic load

Based on sections 1-5-5 and 1-9-4 of $3^{\text {rd }}$ revision of Iranian 2800 standard of seismic provision, moment frames should be able to resist $25 \%$ of the structural lateral load, independently.

In this procedure, after completion of structural design and verification of all the passed beam and column members, braces are removed and the seismic load is reduced to $25 \%$ of its initial value. Then, the design procedure is performed again, and the moment frame structure should comply with allowable code ranges.

\section{Using load combinations including amplified seismic loads in design}

Load combinations including amplified seismic loads are resulted from replacing the seismic loads $E$ with $\Omega$.E in normal load combinations, based on sections 10-1 or 10-2. These load combination consist of:
a) Allowable stress method:
$0.75(\mathrm{D}+\mathrm{L}+\Omega 0 \mathrm{E})$
$0.75(\mathrm{D}+\Omega 0 \mathrm{E})$

b) Limit states method:

$\mathrm{D}+1.2 \mathrm{~L}+1.2 \Omega 0 \mathrm{E}$

$0.85 \mathrm{D}+1.2 \Omega 0 \mathrm{E}$ 
Table 1. Over-strength factor $\Omega 0$ for different lateral load resisting systems

\begin{tabular}{|l|l|}
\hline Lateral load resisting system type & $\mathbf{\Omega}_{\mathbf{0}}$ \\
\hline All steel moment frames & 3.0 \\
\hline $\begin{array}{l}\text { All simply supported frames with } \\
\text { concentrically or eccentrically steel braced } \\
\text { frames }\end{array}$ & 2.0 \\
\hline All dual or combined systems & 2.5 \\
\hline
\end{tabular}

\section{Nonlinear static analysis}

Nonlinear static analysis is used to analyze the selected models in this research.

\subsection{Nonlinear static pushover analysis}

Nonlinear model is defined in sections that have the highest potential of undergoing nonlinear inelastic behavior. For example in fixed ended beams, flexural plastic hinges are defined in the beginning and end of member, and in columns, if no concentrated load is present, flexural plastic hinges are defined in the beginning and end of column, again. In this case, hinge properties are representative of nonlinear material behavior. It should be noticed that, the parameters of nonlinear material behavior curve should be presented in tables of retrofitting provision [Powell,2010].

To investigate the structure using this approach, the structure is analyzed considering the real behavior of member materials (inelastic), under an incremental specific uniform load pattern, and the analysis continues until the displacement of a specific point in the structure (control point displacement) reaches the precalculated limit. This displacement that is calculated based on a specific retrofit goal, is called target or demand displacement and is the base of the structural members. Deformation, rotation and internal forces of the members are studied at this stage (calculating the demand deformation of members is nearly impossible) [Powell,2010].

\section{Analysis procedure of detailed models}

The following assumptions are utilized in analysis procedure of this research.

9.1 Un-loading in nonlinear static analysis
The software should find a way to remove the supported load by the hinge, and then probably re-distribute it on other structural members. When hinges can be un-loaded that their stress-strain, force-displacement, or moment-curvature curves have capacity loss. What we mean by capacity loss is to transfer from point $C$ to $D$ or from point $E$ to $F$ (full rupture). This fact is presented in the following figure [Taghizadeh.R, 2013].

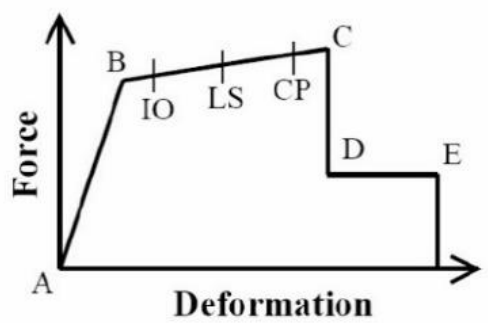

Figur. 2. Severe hinge capacity loss in points $C$ and E [Taghizadeh.R, 2013]

\subsection{Un-loading using restart using secondary stiffness method}

In this approach, if the hinge reaches to the part with negative slope of the stress-strain curve, all the hinges that act nonlinearly, change by utilizing the secant (secondary) stiffness properties, and the analysis is performed again. Secant stiffness of each hinge is defined as the secant of the line connecting $O$ to $X$ in stressstrain curve. The point $\mathrm{O}$, is the stress-strain in start of the analysis that usually includes the stresses resulting from gravitational loads. The point $X$, is the current point on the curve, if the slope of stress-strain curve in this point is either positive or zero. Otherwise, it is on the lower end of the negative slope section of the stress-strain curve. When the load is reapplied at the beginning of the analysis, after that the hinge is retrieved based on the given stress-strain curve, each hinge is displaced along secant slope to reach the point $X$. This procedure is similar to that of FEMA 273, and would be meaningful if incremental load analysis is changed to incremental cyclic loading instead of uniform static load. Performance of this procedure is lower than the other two. The number of required stages is increased relative to square of target displacement in this procedure. This 
procedure is very efficient, if the gravitational load is small, and no rotation divergence will happen. When the stress in the hinge under gravitational loads is so large that the secant of the $\mathrm{O}$ to $\mathrm{X}$ connecting line becomes negative, this procedure won't be efficient anymore. In other words, this procedure can provide convergence in cases which the other two procedures diverge due to small negative slope (almost horizontally). The following picture illustrates the obtained pushover analysis curve using this procedure. The solid and dotted lines in the picture are the pushover curve when the Save Positive Increments Only is activated and deactivated respectively [Taghizadeh.R, 2013].

Considering the expressed explanations and divergence in analytical models and load patterns, secondary stiffness redistribution method is used in this research.

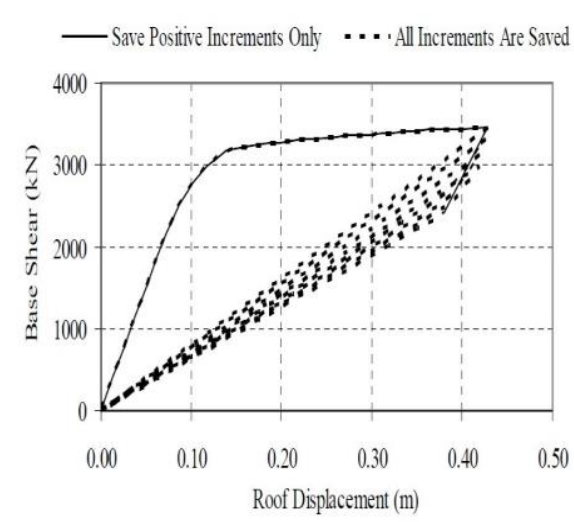

Figur. 3. Comparison of pushover curves between the restart method and secant stiffness method [Taghizadeh.R, 2013]

\section{Analyzing the results}

10.1 Grouping and data analysis

Table 2. Segregated properties of collapse prevention level exceeded hinges of different structural members

\begin{tabular}{|c|c|c|c|c|c|c|c|c|c|}
\hline \multirow{2}{*}{ Model } & \multirow{2}{*}{$\begin{array}{c}\text { Number } \\
\text { of Stories }\end{array}$} & \multicolumn{2}{|c|}{$\begin{array}{c}\text { Number of CP level } \\
\text { exceeded hinges in } \\
\text { columns of braced } \\
\text { bays }\end{array}$} & \multicolumn{2}{c|}{$\begin{array}{c}\text { Number of CP level } \\
\text { exceeded hinges in } \\
\text { columns of moment } \\
\text { frames }\end{array}$} & \multicolumn{2}{c|}{$\begin{array}{c}\text { Number of CP } \\
\text { level exceeded } \\
\text { hinges in beams }\end{array}$} & \multicolumn{2}{c|}{$\begin{array}{c}\text { Number of CP } \\
\text { level exceeded } \\
\text { hinges in braces }\end{array}$} \\
\cline { 2 - 11 } & Push X & Push Y & Push X & Push Y & Push X & Push Y & \multicolumn{2}{c|}{ Push X } & Push Y \\
\hline 1 & 5 & 0 & 0 & 0 & 0 & 8 & 8 & 0 & 0 \\
\hline 2 & 5 & 0 & 0 & 3 & 0 & 6 & 10 & 0 & 0 \\
\hline 3 & 5 & 0 & 0 & 0 & 0 & 10 & 10 & 0 & 0 \\
\hline 4 & 5 & 0 & 0 & 0 & 0 & 10 & 10 & 0 & 0 \\
\hline 5 & 5 & 0 & 0 & 0 & 0 & 8 & 8 & 0 & 0 \\
\hline 6 & 5 & 2 & 4 & 0 & 0 & 12 & 12 & 0 & 0 \\
\hline 7 & 5 & 4 & 4 & 0 & 0 & 12 & 12 & 0 & 0 \\
\hline 8 & 5 & 3 & 4 & 0 & 0 & 12 & 12 & 0 & 0 \\
\hline 9 & 5 & 4 & 4 & 0 & 0 & 12 & 12 & 0 & 0 \\
\hline 10 & 5 & 0 & 0 & 0 & 0 & 12 & 12 & 0 & 0 \\
\hline 11 & 5 & 0 & 0 & 0 & 0 & 12 & 12 & 0 & 0 \\
\hline 12 & 5 & 0 & 0 & 0 & 0 & 12 & 12 & 0 & 0 \\
\hline 13 & 5 & 0 & 0 & 0 & 0 & 12 & 12 & 0 & 0 \\
\hline 14 & 5 & 0 & 0 & 3 & 0 & 20 & 20 & 0 & 0 \\
\hline 15 & 8 & 0 & 0 & 0 & 2 & 16 & 16 & 0 & 0 \\
\hline 16 & 8 & 4 & 0 & 43 & 12 & 22 & 16 & 0 & 0 \\
\hline 17 & 8 & 0 & 0 & 0 & 1 & 14 & 10 & 0 & 1 \\
\hline 18 & 8 & 0 & 0 & 2 & 1 & 14 & 16 & 0 & 0 \\
\hline 19 & 8 & 0 & 0 & 0 & 0 & 14 & 14 & 0 & 0 \\
\hline 20 & 8 & 0 & 0 & 6 & 2 & 28 & 28 & 0 & 0 \\
\hline 21 & 8 & 4 & 0 & 0 & 1 & 24 & 24 & 0 & 0 \\
\hline 22 & 8 & 0 & 0 & 4 & 8 & 24 & 24 & 0 & 0 \\
\hline 23 & 8 & 2 & 2 & 0 & 0 & 24 & 24 & 0 & 0 \\
\hline 24 & 8 & 2 & 3 & 0 & 2 & 36 & 36 & 0 & 0 \\
\hline 25 & 8 & 0 & 1 & 1 & 1 & 30 & 30 & 0 & 0 \\
\hline 26 & 8 & 0 & 0 & 0 & 0 & 36 & 36 & 0 & 0 \\
\hline 27 & 8 & 2 & 0 & 2 & 2 & 30 & 30 & 0 & 0 \\
\hline 28 & 8 & 0 & 0 & 3 & 8 & 32 & 32 & 0 & 0 \\
\hline
\end{tabular}




\subsubsection{First group}

Models no. 1 through 5 consist of low rise 5 story structures, having braced bay length of $10 \%$ of perimeter of the structure, and number of braced bays as two 5 meter bays in each direction. The best structural models in this group was were models 1 and 5 from design and engineering view. They also have the least number of hinges with performance level of collapse prevention. Models no.2 and 4 performed undesirably.

\subsubsection{Second Group}

Models no. 6 through 9 consist of low rise 5 story structures, having braced bay length of 15$20 \%$ of perimeter of the structure, and number of braced bays as four 5 meter bays in each direction. From design and engineering view, there's no significant difference between the models of this group. Though, model no.6 have the least number of hinges with performance level of collapse prevention. Models no.7 and 9 performed undesirably.

\subsubsection{Third Group}

Models no. 10 through 14 consist of low rise 5 story structures, having braced bay length of $25-30 \%$ of perimeter of the structure, and number of braced bays as six 5 meter bays in each direction. No significant difference can be seen between the models no.10 through 13 of this group. Though, model no.10 have the least number of hinges with performance level of collapse prevention. Model no.14 performance was the worst.

\subsubsection{Fourth Group}

Models no. 15 through 19 consist of mid-rise 8 story structures, having braced bay length of $10 \%$ of perimeter of the structure, and number of braced bays as two 5 meter bays in each direction. From design and engineering view, model no.19 was the best of this group, and also this model preforms well in having the least number of hinges with performance level of collapse prevention. Models no.16 and 17 are undesirable models of this group.

\subsubsection{Fifth Group}

Models no. 20 through 23 consist of mid-rise 8 story structures, having braced bay length of $15-20 \%$ of perimeter of the structure, and number of braced bays as four 5 meter bays in each direction. Despite the insignificant differences of the models of this group, model no. 19 was the best, from design and engineering view, and also this model is one of the best performers in having the least number of hinges with performance level of collapse prevention. Model no.22 is among the undesirable models of this group.

\subsubsection{Sixth Group}

Models no. 24, 26 and 27 consist of mid-rise 8 story structures, having braced bay length of $25-30 \%$ of perimeter of the structure, and number of braced bays as six 5 meter bays in each direction. Neglecting the model no. 25 that is irregular, model no. 27 was the best, from design and engineering view, and also this model is one of the best performers in having the least number of hinges with performance level of collapse prevention. Model no.24 performs undesirably in this group.

\subsubsection{Seventh Group}

Models no. 25 and 28 consist of mid-rise 8 story structures, having braced bay length of $25-30 \%$ of perimeter of the structure, and number of braced bays as six 5 meter bays in each direction. Model no. 25 was the best, from design and engineering view, and also this model is one of the best performers in having the least number of hinges with performance level of collapse prevention. Model no.28 performs undesirably in this group.

\section{Conclusion}

1. Among the models of low rise 5 story structures, the best model with residential and administrative applications, is the model no. 6 . If we can't take the risk of that model, model no.10 would be one of the best models. Moreover, generally, except the models no. 2 and 14 (the irregular ones), other models are not significantly different from each other. It can be concluded that for 5 story structures, having the similar condition of bays, $10-20 \%$ of perimeter of the structure, would be a desirable value for length of braced bays. It can be seen that in 5 story models, structures with one or two braced bays in each direction, would be of appropriate models, and more braced bays would be ineffective in weight reduction. 


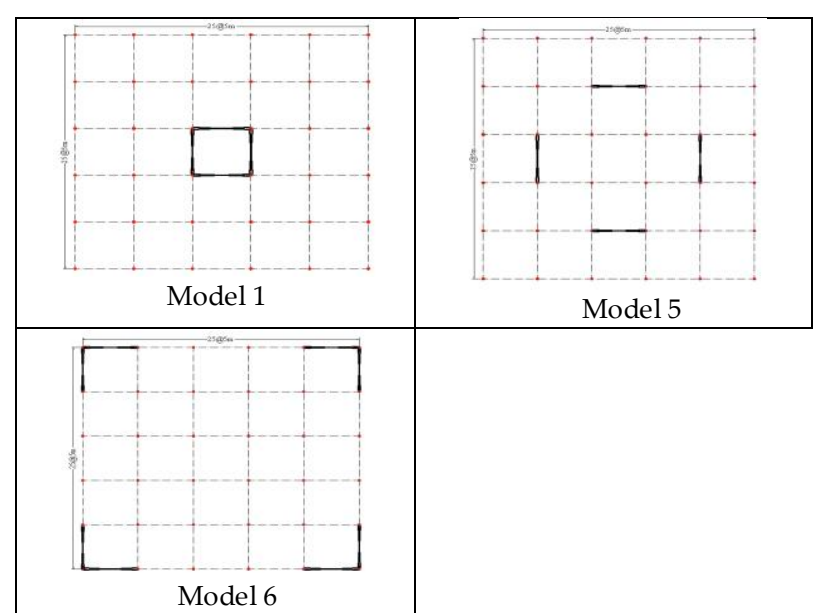

Figur.4. Ideal models with 1 or 2 braced bays in low rise 5 story structures

2. Among the models of mid-rise 8 story structures, the best models with residential and administrative applications, are the models no. 23 and 25. The position of braced frames would be more critical in comparison to their numbers. From the numbers of braced bays view, 20-30\% of perimeter of the structure, would be a desirable value for length of braced bays. Also, irregular models, such as models no. 16 and 28, would not be appropriate models, because of the higher number of hinges with performance level of collapse prevention, due to moment frames' bigger share in resisting lateral load, and secondary torsional effects. It was seen that in 8 story models, structures with two or three braced bays in each direction, would be of appropriate models.

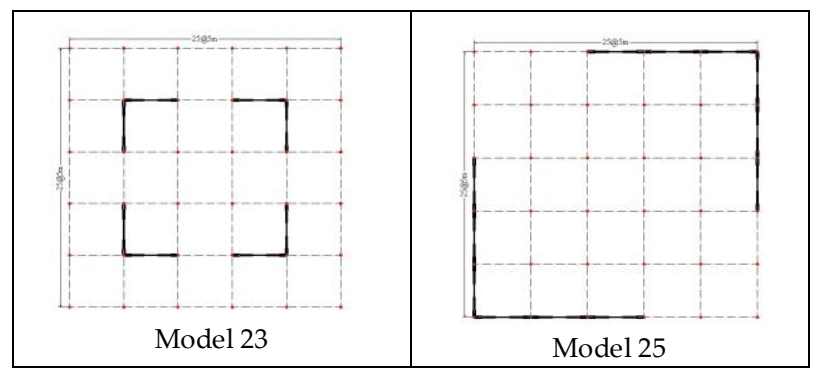

Figur.5. Ideal models with 2 or 3 braced bays in mid-rise 8 story structures

3. Comparison between low and mid-rise structures revealed that with increase in structural height, the number of required braced bays is increased. It can be seen in 5 and 8 story models, presented in this research, where the number of required braced bays was increased form $10-20 \%$ of perimeter of the structure to 20 $30 \%$ of that.

4. Mean over-strength factors of aforementioned groups are as follows:

Table 3. Mean of desirable group over-strength factors

\begin{tabular}{|l|l|l|}
\hline Group & $\begin{array}{c}\text { Over-strength }(\boldsymbol{\Omega}) \text { in Push } \mathbf{X} \\
\text { direction }\end{array}$ & $\begin{array}{c}\text { Over-strength }(\boldsymbol{\Omega}) \text { in Push } \mathbf{Y} \\
\text { direction }\end{array}$ \\
\hline $\begin{array}{l}1^{\text {st }} \text { (Models no. } \\
1 \text { through 5) }\end{array}$ & 1.5 & 1.35 \\
\hline $2^{\text {nd }}$ (Models no. 6 through 9) & 1.3 & 1.3 \\
\hline $3^{\text {rd }}$ Models no. 10 through 14) & 1.3 & 1.3 \\
\hline $4^{\text {th }}$ (Models no. 15 through 19) & 1.5 & 1.5 \\
\hline $5^{\text {th }}$ (Models no. 20 through 23) & 1.3 & 1.3 \\
\hline $6^{\text {th }}$ (Models no. 24,26 and 27) & 1.3 & 1.3 \\
\hline 7 th (Models no. 25 and 28) & 1.35 & 1.35 \\
\hline
\end{tabular}

5. Though the amplified seismic load function is controlled in models which columns are connected to braces in 2 directions, and seismic loads are applied in those 2 directions, number of damage hinges (Exceeding $\mathrm{CP}$ ) is significantly increased in comparison to the models with straggly braces. As the increase in axial force of these columns leads to decrease in their moment capacity (despite controlling the amplified seismic load provision), columns in dual systems that resist flexure, would be damaged and exceed the collapse threshold much sooner than other columns. Finally, it's recommended that in these structures (dual systems), when calculating the moment capacity of the columns connected to the braces, the effects of over-strength factor should be noticed. 
This important fact is not presented in Iranian or even American codes and provisions(Figur.6).

Table 4. Elastic strength and maximum strength limit of the structures modeled

\begin{tabular}{|c|c|c|c|c|c|c|c|c|c|c|c|}
\hline \multirow{3}{*}{$\begin{array}{l}\text { Mo } \\
\text { del }\end{array}$} & \multirow{3}{*}{$\begin{array}{l}\text { Number } \\
\text { of Stories }\end{array}$} & \multicolumn{4}{|c|}{$\begin{array}{l}\text { Elastic strength limit of the } \\
\text { structure }\end{array}$} & \multicolumn{4}{|c|}{$\begin{array}{l}\text { Maximum strength limit of } \\
\text { the structure }\end{array}$} & \multicolumn{2}{|c|}{$\begin{array}{c}\text { Over- } \\
\text { strength } \\
\Omega \\
\end{array}$} \\
\hline & & \multicolumn{2}{|c|}{ Push X } & \multicolumn{2}{|c|}{ Push Y } & \multicolumn{2}{|c|}{ Push X } & \multicolumn{2}{|c|}{ Push Y } & \multirow[b]{2}{*}{$\begin{array}{l}\text { Pus } \\
\text { hX }\end{array}$} & \multirow[b]{2}{*}{$\begin{array}{l}\text { Pus } \\
\text { h Y }\end{array}$} \\
\hline & & Step & $\begin{array}{l}\text { Shear } \\
\text { (Ton) }\end{array}$ & Step & $\begin{array}{l}\text { Shear } \\
\text { (Ton) }\end{array}$ & Step & $\begin{array}{l}\text { Shear } \\
\text { (Ton) }\end{array}$ & Step & $\begin{array}{l}\text { Shear } \\
\text { (Ton) }\end{array}$ & & \\
\hline 1 & 5 & 2 & 315 & 3 & 324 & 6 & 400 & 6 & 418 & 1.3 & 1.3 \\
\hline 2 & 5 & 3 & 293 & 3 & 426 & 33 & 599 & 6 & 591 & 2 & 1.4 \\
\hline 3 & 5 & 3 & 344 & 1 & 247 & 6 & 457 & 2 & 354 & 1.3 & 1.4 \\
\hline 4 & 5 & 3 & 328 & 3 & 325 & 6 & 428 & 6 & 423 & 1.3 & 1.3 \\
\hline 5 & 5 & 3 & 289 & 3 & 288 & 6 & 402 & 10 & 389 & 1.4 & 1.35 \\
\hline 6 & 5 & 3 & 376 & 3 & 667 & 6 & 484 & 4 & 467 & 1.3 & 1.3 \\
\hline 7 & 5 & 3 & 365 & 3 & 383 & 4 & 465 & 6 & 501 & 1.3 & 1.3 \\
\hline 8 & 5 & 3 & 367 & 3 & 371 & 5 & 467 & 5 & 472 & 1.3 & 1.3 \\
\hline 9 & 5 & 3 & 374 & 3 & 375 & 7 & 481 & 7 & 484 & 1.3 & 1.3 \\
\hline 10 & 5 & 3 & 415 & 3 & 421 & 4 & 530 & 4 & 551 & 1.3 & 1.3 \\
\hline 11 & 5 & 3 & 544 & 3 & 517 & 4 & 687 & 5 & 669 & 1.3 & 1.3 \\
\hline 12 & 5 & 3 & 435 & 3 & 441 & 5 & 542 & 5 & 550 & 1.25 & 1.25 \\
\hline 13 & 5 & 3 & 430 & 2 & 422 & 5 & 541 & 4 & 540 & 1.3 & 1.3 \\
\hline 14 & 5 & 3 & 470 & 3 & 470 & 24 & 691 & 8 & 683 & 1.5 & 1.45 \\
\hline 15 & 8 & 2 & 508 & 2 & 516 & 3 & 674 & 3 & 687 & 1.3 & 1.3 \\
\hline 16 & 8 & 2 & 618 & 2 & 592 & 39 & 1048 & 42 & 980 & 1.7 & 1.7 \\
\hline 17 & 8 & 2 & 480 & 3 & 358 & 9 & 660 & 21 & 693 & 1.4 & 1.95 \\
\hline 18 & 8 & 2 & 478 & 2 & 500 & 5 & 673 & 5 & 700 & 1.4 & 1.4 \\
\hline 19 & 8 & 2 & 385 & 2 & 506 & 11 & 561 & 3 & 663 & 1.5 & 1.3 \\
\hline 20 & 8 & 2 & 564 & 2 & 534 & 3 & 743 & 3 & 700 & 1.3 & 1.3 \\
\hline 21 & 8 & 2 & 481 & 2 & 507 & 5 & 642 & 7 & 686 & 1.3 & 1.35 \\
\hline 22 & 8 & 2 & 557 & 2 & 561 & 3 & 717 & 4 & 727 & 1.3 & 1.3 \\
\hline 23 & 8 & 2 & 570 & 2 & 581 & 3 & 740 & 3 & 756 & 1.3 & 1.3 \\
\hline 24 & 8 & 2 & 536 & 2 & 560 & 3 & 684 & 3 & 706 & 1.3 & 1.3 \\
\hline 25 & 8 & 2 & 718 & 3 & 709 & 3 & 917 & 3 & 907 & 1.3 & 1.3 \\
\hline 26 & 8 & 2 & 584 & 2 & 589 & 3 & 752 & 3 & 760 & 1.3 & 1.3 \\
\hline 27 & 8 & 2 & 609 & 2 & 618 & 3 & 768 & 3 & 781 & 1.3 & 1.3 \\
\hline 28 & 8 & 2 & 663 & 2 & 663 & 5 & 923 & 3 & 923 & 1.4 & 1.4 \\
\hline
\end{tabular}



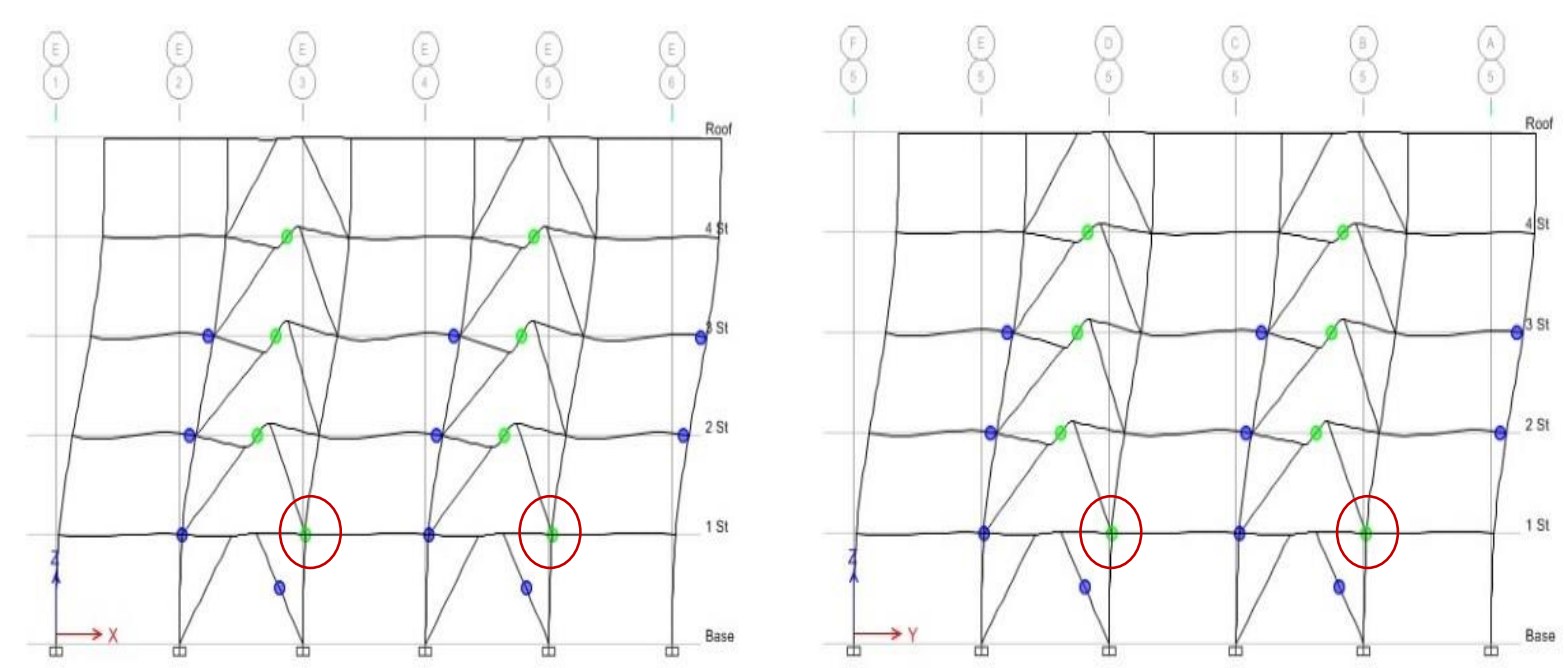

Fig. 6. Results of pushover analysis, development of plastic hinges exceeding collapse prevention levels in 2 columns connected to braces (Right: Push Y, Left: Push X)

\section{References}

Continual revision committee (2005). "3rd revision of Iranian 2800 standard of seismic revision - Code for seismic design of structures" Road, Housing \& Urban Development Research Center

Continual revision committee (2013). "Code 6 of Iranian national building requirements" Road, Housing \& Urban Development Research Center

Continual revision committee (2013). "Code 10 of Iranian national building requirements" Road, Housing \& Urban Development Research Center

Merovich, A.T., Nicoletti, J.P. and Hartle, E. (1982). "Eccentric Bracing in Tall Buildings," ASCE Journal of the Structural Division, 108(ST9), September, pp. 2066-2079

Richards, Paul.W. (2010). "Estimating the stiffness of eccentrically braced frames (EBFs)." ASCE Practice Periodical on Structural Design and Construction.

Roeder, C.W. and Popov, E.P. (1978). “Eccentrically Braced Steel Frames for
Earthquakes," ASCE Journal of the Structural Division, ST3, March, pp. 391-411

Popov, E.P., Engelhardt, M.D. and Ricles, J.M. (1989). "Eccentrically Braced Frames: U.S. Practice," AISC Engineering Journal, Second Quarter, pp. 66-80.

Taghizadeh, R. (2013) “Performance based design and rehabilitation of structures using pushover analysis in ETABS nad SAP" Collegiate books publications 